\title{
Age at Menarche and Menstrual Pattern of Elementary School Students in Medan
}

\author{
Nurdiani, Evi Kamelia, Rusdi Andid, Ani Ariani, Hakimi, Endang D Hamid \\ (Department of Child Health, Medical School University of North Sumatera - \\ Adam Malik Hospital, Medan)
}

\begin{abstract}
ABSTRACr This study aimed to determine the age at menarche and its influencing factors and the pattern of menstrual cycles in elementary school students in Medan. Subjects were 227 female students in six primary schools (private and government) in Medan municipal, during October until November 1995. Most students experienced menarche in government primary school (GPS: $35.8 \%$ ) and private primary school (PPS: $24 \%$ ), at the age of 10-12 years. The mean age at menarche of these students in government primary school was 11.41 (SD 0.95) years while in private primary school it was 10.65 (SD 0.78) years. Subjects who had had menarche had better nutritional status than who had not $(p<0,001)$. Sports activities are also associated with age at menarche $(p<0.001)$. On the other hand family's economical status and maternal age at menarche were not siginicantly associated with age atmenarche $(p>0.05)$. Most students who had had menarche had regular menstrual cycle; the duration of menarche was 4-6 days for GPS and 3 days for PPS. Dysmenorrhea was a common finding in the first three months of menstruation cycle but gradually diminishing with time. The duration of menstrual cycle was 25-34 days. These findings are useful as a guide for the parents, especially when mothers planning the best time/ the moment to discuss about reproduction and sexual counseling with her daughter. [Paediatr Indones 1999; 39:75-84]
\end{abstract}

\section{Introduction}

Menstruation is a specific biological nature of adolescent female. The first menstruation is called menarche, which is actually, the peak of the whole series of changes occurring on adolescent girls growing to puberty. ${ }^{1-4}$ These consist of hormonal, physical and mental changes which are caused by some gland interaction in the body. The 
main control center of the change is hypothalamus cooperating with pituitary. Due to unkonown cause, 4 years before menarche, hypothalamus has released a certain substance as a releasing factor which causes hypophysis releases certain substances; one of them is responsible for the initiation of menarche ${ }^{5.6}$ In some culture menarche is considered as a sign of maturity, thus women who has had menarche are considered ready for marry and giving a birth. ${ }^{3}$ The age at menarche varies in different populations. A few decades ago adolescent girls had their menarche in their seventeenth. Now in Europe and America, age at menarche tends to be younger. In developing countries, adolescents have their menarche in the mean of 13.5 years old. In England the average age at menarche is in 13 years compared with 15 years in the previous decade. Study in Australia also shows that age at menarche tends to be younger. The later of menarche, the faster the occurrence of menopause and the reverse. ${ }^{3}$

Some surveys in Indonesia show that the age at menarche ranges between 11 to 16 years. Menarche age is believed to be influenced by some factors such as social economy, the size of family, sport activities, environment, mental and nutrition status. ${ }^{5}$ The aim of this study was to describe the age at menarche and its influencing factors as well as the menstruation pattem adolescents.

\section{Methods}

This study was conducted from October to Novernber 1995. Subjects were all the fifth and the sixth grades female students in 3 government primary schools and 3 private schools in Medan, North Sumatra. Data were collected by questionnaire. Physical examination was performed to determine the secondary sexual characteristics. Antroprometrical measurements were recorded, including body weight (measured by using DETECTO scale with $0.1 \mathrm{~kg}$ sensitivity), body height (measured by using stadiometer with $0.1 \mathrm{~cm}$ of accuracy).

Determination of nutritional status was based on body weight index with standard reference from National Center for Health and by WHO (NCHS-WHO). We modified the classification of nutritional status of "1991 Semiloka Antropometry" into 'poor' (less than - 2 SD), good (from -1 SD to + 1 SD), and obese (more than $1 \mathrm{SD}$ ).

Economical status was regarded as good if it was more than income per capita per month according to 1990 World Bank, i.e. more than Rp. 65 000. Sport activities were classified based on weekly frequency, i.e. light sport for once a week, moderate sports for twice in week and heavy sport for three times or more in a week.

The duration of menstruation was calculated from the first up till the last day of bleeding. The menstrual cycle was calculated from the first day of menstruation to the first day of the next cycle. Menstrual pattern was considered regular if it occurred monthly appropriate to the menstrual cycle; otherwise it was considered irregular. 
With menstruation in the first 3 month we meant 3 consecutive cycles after menarche, while menstruation in the last three months meant the last 3 cycles prior to the study. Data were presented in the form of text and table. Qualitative analysis was performed using two-sided chi square test. The level of significance was $\mathrm{p}<0.05$.

\section{Results}

From the six primary schools studied, there were 227 female students who were in the fifth and sixth classes, aging from 8 to 15 years old. In government primary school (GPS), there were 95 female students (aged 8 to 15 years), while in private primary school (PPS), there were 132 female students (aged 8 to 13 years). Most of them belonged to 10 to 11 years age group both in GPS and PPS $(49.5 \%$ and $81.8 \%$, respectively).

Of the 227 studerits, $66(59.8 \%)$ had experienced menarche. In GPS, out of 95 students, $34(35.8 \%)$ had had menarche, while in PPS, $32(24 \%)$ out of 132 students had had menarche. See Table 1. The average of age at menarche in GPS was 11.41 years old (SD 0.95), and in PPS 10.65 (SD 0.78) years; the difference was not significant. The average of age at menarche for the mothers of GPS students was 14.08 (SD 1.31) years, whilst for PPS students it was 13.06 (SD 0.94) years. There was no apparent association between the age of menarche of mothers and of the students.

Tables 2 to 4 show that the nutritional status, calculated based on weight/age, height/age, and weight/height was associated with the age of menarche, i.e., adolescents who had experienced menarche had a better nutritional status than those who had never experienced menarche.

Association between economical status and menarche is depicted in Table 5 . It shows that in the group of adolescents who had experienced menarche, $59.1 \%$ were of high economical status, while in those who had not experienced menanche the figure was $64 \%$; this difference was not statistically significant. On the other hand, sport activity was associated with the age at menarche; adolescents who had had their menarche were more engaged in sport activities than those who had never had menarche. See Table 6.

The menstrual pattern found in the first 3 months and the last 3 months equal for both students of GPS and PPS i.e. 52\% and 53\% respectively. There are 3 female students of GPS and 11 female students of PPS who had only two menstrual cycles. The time of menstruation of GPS were 4 to 6 months in the first and the last 3 months. In female student of PPS, as a matter of fact, have the average time of menstruation for 3 days in the first month but the last 3 month, it was found 4 to 6 days. The cycles time of female student of GPS and PPS was 25-34 days. 
78 Age at mearche and mentrual pattern of adolescents

Table 1. Distribution of age at menarche on female students and their mothers

\begin{tabular}{ccccccccc}
\hline \multirow{2}{*}{$\begin{array}{c}\text { Age ot menarche } \\
\text { (yr.) }\end{array}$} & \multicolumn{3}{c}{ Female students } & \multicolumn{3}{c}{ Mother female students } \\
\cline { 2 - 10 } & \multicolumn{2}{c}{ GPS } & \multicolumn{2}{c}{ PPS } & \multicolumn{2}{c}{ GPS } & \multicolumn{2}{c}{ PPS } \\
\cline { 2 - 10 } & $n$ & $\%$ & $n$ & $\%$ & $n$ & $\%$ & $n$ & $\%$ \\
\hline$<8$ & 0 & 0 & 0 & 0 & 0 & 0 & 0 & 0 \\
9 & 0 & 0 & 1 & 3.1 & 0 & 0 & 0 & 0 \\
10 & 7 & 20.6 & 13 & 40.6 & 0 & 0 & 1 & 3.1 \\
11 & 10 & 29.4 & 13 & 40.6 & 0 & 0 & 1 & 3.1 \\
12 & 13 & 38.2 & 5 & 15.6 & 2 & 23.5 & 10 & 31.3 \\
13 & 4 & 11.8 & 0 & 0 & 8 & 29.5 & 9 & 28.1 \\
14 & 0 & 0 & 0 & 0 & 10 & 29.4 & 11 & 34.4 \\
$\geq 15$ & 0 & 0 & 0 & 0 & 14 & 41.2 & 1 & 3.1 \\
\hline Total & 34 & 100 & 32 & 100 & 34 & 100 & 32 & 100 \\
\hline
\end{tabular}

Table 2. Relationship between nutrition status (body weight/age) and menarche

\begin{tabular}{|c|c|c|c|c|c|}
\hline \multicolumn{6}{|c|}{ Menarche } \\
\hline \multirow[t]{2}{*}{ Nutrition status } & \multicolumn{2}{|c|}{ Yes } & \multicolumn{2}{|c|}{ No } & \multirow[t]{2}{*}{ Total } \\
\hline & $n$ & $\%$ & $n$ & $\%$ & \\
\hline Poor & 2 & 3.0 & 68 & 42.2 & 70 \\
\hline Good & 64 & 97.0 & 93 & 57.8 & 157 \\
\hline Total & 66 & 100.0 & 161 & 100.0 & 227 \\
\hline
\end{tabular}

\section{Discussion}

Information on the average age at menarche can help parents or educators in implementing sex education. In this study we found the average age at menarche of students in government school was higher than that in private students, i.e. 11.41 (SD 
0.95 ) and 10.65 (SD 0.78) years old, respectively; however, the difference was not significant. Our results also suggest that age at menarche tends to be earlier than the previous year. ${ }^{5,7.8}$ Rousyidi in 1991 conducted a study on government junior high school students and private junior high school students in Medan. He found that age at menarche is 12.37 (SD 1) years, and 13.11 (SD 1.04) years. ${ }^{3}$ A study in England indicates that age at menarche is 13 years. ${ }^{3}$ In the United States the average of the age at menarche is in 12.5 years old.$^{9}$ Others study results conducted in Indonesia on menarche is written in Table 8 and from other countries in Table 9.

Table 3. Relationship between nutrition status (height/age) and menarche

\begin{tabular}{|c|c|c|c|c|c|}
\hline \multirow{3}{*}{ Nutrition status } & \multicolumn{4}{|c|}{ Menarche } & \multirow{3}{*}{ Total } \\
\hline & \multicolumn{2}{|c|}{ Yes } & \multicolumn{2}{|c|}{ No } & \\
\hline & $n$ & $\%$ & $n$ & $\%$ & \\
\hline Poor & 10 & 15.2 & 71 & 44.1 & 81 \\
\hline Good & 56 & 84.8 & 90 & 55.9 & 146 \\
\hline Total & 66 & 100.0 & 161 & 100.0 & 227 \\
\hline
\end{tabular}

Table 4. Relationship between nutrition status (body weight/height) and menarche

\begin{tabular}{lccccc}
\hline \multicolumn{7}{c}{ Menarche } \\
\hline Nutritional status & \multicolumn{7}{c}{+} & & & Total \\
\hline & $n$ & $\%$ & $n$ & $\%$ \\
\hline Poor & 8 & 12.1 & 17 & 10.6 & 25 \\
Good & 45 & 68.2 & 84 & 52.1 & 129 \\
Over & 13 & 19.7 & 60 & 37.3 & 73 \\
\hline \multicolumn{1}{c}{ Total } & 66 & 100.0 & 161 & 100.0 & 227 \\
\hline
\end{tabular}

$$
x^{2}=6.708 ; d f=2 ; p<0.05
$$


Table 5. Relationship between family's economical status and menarche

\begin{tabular}{ccccccc}
\hline \multicolumn{7}{c}{ Menarche } \\
\hline $\begin{array}{c}\text { Family's economical } \\
\text { status }\end{array}$ & \multicolumn{2}{c}{ Yes } & No & Total \\
\hline & $n$ & $\%$ & $n$ & $\%$ & \\
\hline High & 39 & 59.1 & 103 & 64.0 & 142 \\
Low & 27 & 40.9 & 58 & 36.0 & 85 \\
\hline Total & 66 & 100 & 161 & 100 & 227 \\
\hline$x^{2}=0.477$ & & $d f=1$ & $p>0.05$ & &
\end{tabular}

Table 6. Relationship between sport activities and menarche

\begin{tabular}{|c|c|c|c|c|c|}
\hline \multicolumn{6}{|c|}{ Menarche } \\
\hline \multirow[t]{2}{*}{ Sport activities } & \multicolumn{2}{|c|}{ Yes } & \multicolumn{2}{|c|}{ No } & \multirow[t]{2}{*}{ Total } \\
\hline & $n$ & $\%$ & $n$ & $\%$ & \\
\hline None & 5 & 7.6 & 46 & 28.6 & 51 \\
\hline Once a week & 18 & 27.3 & 60 & 37.3 & 78 \\
\hline Twice a week & 29 & 43.9 & 30 & 18.6 & 59 \\
\hline$>$ Twice a week & 14 & 21.2 & 25 & 15.6 & 39 \\
\hline Total & 66 & 100.0 & 161 & 100.0 & 227 \\
\hline & & $d f=3$ & $p<0$. & & \\
\hline
\end{tabular}

Nutrition is one factor that can influence the age at menarche. The growth before the menarche time, it is found a periode of fast body growth. This period is, then, called "adolescent growth spurt" and it is related to the process of menarche. If the adolescent growth spurt falls, it is the time of the real menarche process, so that nutrition status can influence the growth of the body and cause disturbance in hypothalamus caused by secretion of irregular gonadotropin and it also cause lateness of the menarche. This study, actually there is a significaritly between the nutrition status and menarche $(p<0.001)$. In study conducted by Lail 1978 and Dale 1979 state that nutrition status can influence age at menarche. ${ }^{7}$ A study conducted by Satyanarayana 
1970 in Hyderabad states that menarche time (age at menarche) in girl with poor nutrition status (kwashiorkor or marasmus) can be late in 15.2 years old compared to good nutrition status in 13.7 years old. ${ }^{14}$ By knowing the age at menarche on female adolescent girl, it needs to increase the nutrition status as soon as possible so that in the second faster growth/ adolescent growth spurt, the growth can be reached perfectly. A good economical status of the family in this study had no significant relationship with menarche $(p>0.05)$. Rousyidi also says that the first menstruation may depend on social economical status. ${ }^{3}$

Table 7. Menstrual pattern of female students at six primary schools

\begin{tabular}{|c|c|c|c|c|c|c|c|c|}
\hline & & & & & & & & \\
\hline Menstrual pattern & & & & & & & & \\
\hline & & & & mo & & & & \\
\hline & $n$ & $\%$ & $n$ & $\%$ & $\mathrm{n}$ & $\%$ & $n$ & $\%$ \\
\hline
\end{tabular}

1. Regularity

$\begin{array}{lcccccccc}\text { - regular } & 18 & 52.9 & 27 & 87.1 & 16 & 55.2 & 19 & 79.2 \\ \text { - irregular } & 16 & 47.1 & 4 & 12.9 & 13 & 44.8 & 5 & 20.8\end{array}$

2. Duration of menarche

$\begin{array}{llllllllc}\text { - < } 3 \text { days } & 10 & 29.4 & 6 & 17.7 & 13 & 38.2 & 2 & 5.9 \\ \text { - 4-6 days } & 13 & 38.2 & 14 & 41.2 & 12 & 35.3 & 11 & 32.4 \\ \text { - >7 days } & 11 & 32.4 & 10 & 29.4 & 7 & 20.6 & 8 & 23.5\end{array}$

3. Menstrual cycle (days)

- 21-24

$0 \quad 0$

$0 \quad 0$

$0 \quad 0$

- 25-34

94.1

21

61.8

28

$82.4 \quad 30$

88.2

a >35

0

6

$17.7 \quad 1$

2.9

4. Painful menarche

- always

$$
27
$$

- sometimes

$27 \quad 79.4 \quad 15$

0

$15 \quad 44.1 \quad 14$

$41.2 \quad 8$

23.5

- never

$5 \quad 14.7$

$50.0 \quad 22$

64.7

$\begin{array}{llllll}2 & 5.9 & 3 & 8.8 & 1 & 2.9\end{array}$


Table 8. The average age at menarche, result from studies in Indonesia (1970-1991)

\begin{tabular}{|c|c|c|c|c|}
\hline \multirow{3}{*}{ No } & \multirow{3}{*}{ City } & \multirow{3}{*}{$\begin{array}{l}\text { Study } \\
\text { (years) }\end{array}$} & \multicolumn{2}{|c|}{ The average of menarche } \\
\hline & & & Mean & SD \\
\hline & & & \multicolumn{2}{|c|}{ (years) } \\
\hline 1. & Yogyakarta ${ }^{10}$ & 1970 & 14.48 & 1.15 \\
\hline 2. & Surabaya $^{10}$ & 1977 & 13.50 & 1.60 \\
\hline 3. & Palopo $^{10}$ & 1979 & 15.26 & 1.41 \\
\hline 4. & Toraja $^{10}$ & 1979 & 15.00 & 1.21 \\
\hline 5. & Ujung Pandang ${ }^{10}$ & 1979 & 14.09 & 0.76 \\
\hline 6. & Kayu Agung $^{10}$ & 1980 & 15.32 & 2.19 \\
\hline 7. & Palembang ${ }^{10}$ & 1980 & 13.70 & 2.14 \\
\hline 8. & Jakarta ${ }^{\prime 0}$ & 1980 & 13,26 & 1.33 \\
\hline 9. & Medan $^{3}$ & 1983 & 13.49 & 1.50 \\
\hline 10. & Jakarta $^{7}$ & 1986 & 13.00 & 1.10 \\
\hline 11. & Medan $^{3}$ & 1991 & 13.11 & 1.04 \\
\hline 12. & Medan $^{3}$ & 1991 & 12.37 & 1.00 \\
\hline 13. & Medan $^{3}$ & 1995 & 11.41 & 0.95 \\
\hline
\end{tabular}

Abraham reported that the longer age at menarche is found in female athlete who conduct heavy sport compared with light sport athlete. It is related to the decrease of fat in the body. ${ }^{3}$ Astran et al in Swedia reports that the average of age at menarche of swimmer is earlier than civil who do not any kind of sports. In this study, it is not found a significant relationship between sport activity and menarche $(p<0,001)$. Malina et al also reported high dysmenorrhea incident and irregular menstruation on athlete ${ }^{19}$ In this study, the highest average of menarche were female student who conduct light sport (twice in a week). In this study, special sport classification is implemented, and statistically, it is not found any significant relation of the classifications.

Rizvi's report in India finds correlation between the age at menarche of the children and the mother. The older age at menarche of the mother, the older the age of the child menarche. ${ }^{3}$ It is not found relationship between mother's age at menarche and the child's age at menarche. Menstruation pattern on female adolescent, in this study, has no much differences from existed in the library, i.e. menstruation time for normal cycles is 25 to 32 days (Hartman). ${ }^{3.8}$ In this study the longest duration of the age at 
menarche falls to 25 to 34 days. The longer of age at menarche, the less pain found and in this study the pain is less after the last three month. The result of the study on female adolescent girl is younger than the previous study. Nutrition and sport activity status influence age at menarche. Menstruation pattern, however, has no any difference with available library results.

Table 9. The average age at menarche from study in other countries

\begin{tabular}{llccc}
\hline & & Study & \multicolumn{2}{c}{ The average of menarche } \\
\hline No & \multicolumn{3}{c}{ City } & \multicolumn{3}{c}{ Mean } & SD \\
\cline { 3 - 5 } & & (years) & \multicolumn{2}{c}{ (years) } \\
\hline 1. & Osio" $^{11}$ & 1970 & 13.10 & 0.42 \\
2. & Somalia $^{12}$ & 1972 & 14.78 & 0.07 \\
3. & Tirupati $^{13}$ & 1973 & 13.50 & 0.037 \\
4. & Hyderabad $^{14}$ & 1977 & 14.60 & 0.08 \\
5. & Marwaries $^{15}$ & 1977 & 14.28 & 0.04 \\
6. & France $^{16}$ & 1977 & 13.05 & 0.18 \\
7. & Mahe $^{17}$ & 1978 & 12.84 & 1.08 \\
8. & Ghanaian $^{18}$ & 1986 & 13.98 & 1.42 \\
\hline
\end{tabular}

Nutrition and sport activity status are factor which have significant relationship with menarche. Menstruation pattern on female adolescent student in the six primary schools is suitable to library references and there is no any difference between female GPS students and female PPS students. This result of this study is useful to the parents as guidance in planning a right of giving health reproduction guidance to female adolescent. It is expected to conduct further study in order to see the change of age at menarche at next year in Indonesia.

\section{References}

1. Danukusumo D. Persepsi tentang haid. In: Gangguan haid pada remaja dan dewasa. Jakarta: Balai Penerbit FKUI, 1990; 21-28.

2. Mochtar R. Fisiologi alat-alat kandungan, Sinopsis Obstetri. Valentino Group. Medan $1985 ; 15-20$. 
3. Rousydy A. Penelitian usia rata-rata menars pada remaja putri pelajar di dua SLTP Kodya Medan. Tesis pada laboratorium obstetri \& ginecologi FKUSU, Medan 1991:1-52.

4. Sastrawinata. Wanita dalam berbagai masa kehidupan. In: Prawirohardjo S. Ilmu Kandungan edisi I. Jakarta: Yayasan Bina Pustaka, 1989; 86-89.

5. Affandi B. Fisiologi haid. In: Gangguan haid pada remaja dan dewasa. Jakarta: Balai Penerbit FKUI, 1990;1-6.

6. Hanifah W. Fisiologi haid. Dalam: Prawirohardjo S. llmu Kandungan, 1st ed. Jakarta: Yayasan Bina Pustaka, 1981;37-41.

7. Samsudin. The age at menarche as related to physical growth of junior high school girls in Jakarta. Paediatr Indones 1990;30:254-60.

8. Staf pengajar Ilmu Kesehatan Anak FKUI. Buku Kuliah Ilmu Kesehatan Anak FKUI, Jakarta 1990;149-50.

9. Behrman ER. The endocrine system. In: Nelson textbook of pediatrics. 4th ed, 1992; 1408-8.

10. Boedihartono. Age at menarche in Indonesia. In: Gangguan haid pada remaja dan dewasa. Jakarta: Balai Penerbit FKUI, 1990;9-17.

11. Brundtiand GH, Liestol $\mathrm{K}$, Walloe $\mathrm{L}$. Height, weight and menarcheal age of Oslo schoolchildren during the last 60 years. Ann Hurn Biol 1980;7:307-22.

12. Gallo PG. The age at menarche in Somalia. Ann Hum Biol 1975;2:197-200.

13. Bai KI. Age at menarche in South Indian school girls, Tirupati (AP). Tropical pediatrics and environmental child health 1978; 171-5.

14. Satyanarayana $K$, Naidu AN, Nutrition and menarche in nural Hyderabad. Ann Hum Biol $1979 ; 6: 163-5$.

15. Lail MM, Sinha SP. Age at menarche in different castes of marwary community of Bhagalpur. Indian J Med Res 1978; 67:473-7.

16. Crognier E, Rocha Maria AT: Age at menarche in rural France. Ann Hum Biol 1979;6: $167-9$.

17. Grainger CR. The age of the menarche in school girls on Mahe, Seychelles. Roy Soc Trop Med Hyg 1980; 74:23-4.

18. Adadedov SWK. Menarche age in Ghanaian school girls. Int J Gynecol Obstet 1989; 0:63-8,

19. Malina RM. Age at menarche and selected menstrual characteristics in athletes at different competitive levels and in different dports. Med Sci Sports 1978;10; 218-22. 